\title{
Pelatihan Mindfulness pada Kebahagiaan Penderita Diabetes Melitus Tipe II
}

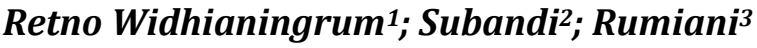 \\ 1,3Fakultas Psikologi dan Ilmu Sosial Budaya, Universitas Islam Indonesia \\ 2Fakultas Psikologi Universitas Gadjah Mada \\ ${ }^{1}$ r.widhianingrum@gmail.com
}

\begin{abstract}
Abstract. This research aims at identifying the effect of mindfulness training on the happiness fo patients of diabetes melitus type II. The subject of the reseach was 8 patients who will be divided into experimental group and control group. The data collection was conducted using Steen Happiness Index (SHI). The Hypothesis that proposed of the research is that there is a difference of happiness between the experimental group which was given mindfulness training treatment and controlled group which was not given the treatment of mindfulness training. The research design used was pre-test post-test control group design.The data obtained were analyzed using non- parametric Mann-Whitney to compare the differences of quality of life scores in pretest, posttest, and follow up between experimental groupand Control group. The result of this study showed that there are not a differences of happiness after the training between experimental group and control group after given, with value of $\mathrm{Z}=-0.959, \mathrm{p}=0.337(\mathrm{p}>0.05)$. in the post test and follow up, the group didn't show any differences of happiness with value of $\mathrm{Z}=-1.200, \mathrm{p}=0,230$ (p>0.05).
\end{abstract}

Keywords: Mindfulness, Happiness, Diabetes melitus.

Abstrak. Tujuan dari penelitian ini adalah untuk dapat melihat pengaruh pelatihan mindfulness terhadap kebahagiaan penderita diabetes melitus. Subjek penelitian ini adalah delapan orang pasien diabetes melitus tipe dua yang dibagi menjadi dua kelompok yaitu kelompok kontrol dan kelompok eksperimen.Kebahagiaan subjek diukur menggunakan skala Steen Happiness Index $(S H I)$. hipotesis penelitian ini adalah adanya perbedaan kebahagiaan pada kelompok eksperimen yang diberikan pelatihan mindfulness dan kelompok kontrol yang tdak diberikan pelatihan mindfulness. Metode yang digunakan adalah pretest-posttest control group design. Data yang diperoleh dianalisis menggunakan metode non-parametrik Mann-Whitney untuk melihat perbedaan skor SHI saat prates, paskates, dan tindak lanjut pada kelompok ekperimen dan kelompok kontrol. Hasil penelitian yang diperoleh menunjukkan bahwa tidak ada perbedaan yang sangat signifikan antara SHI kelompok eksperimen dan kontrol, dengan nilai of $\mathrm{Z}=-0.959, \mathrm{p}=$ 0.337 ( $\mathrm{p}>0.05$ ). Saat tindak lanjut juga tidak menunjukkan adanya perbedaan antara kelompok kontrol dan kelompok eksperimen, dengan nilai $\mathrm{Z}=-1.200, \mathrm{p}=0,230(\mathrm{p}>0.05)$.

Keywords: Mindfulness, Kebahagiaan, Diabetes melitus. 


\section{Pendahuluan}

Setiap manusia pasti menghadapi berbagai peristiwa dalam kehidupannya. Peristiwa-peristiwa yang tidak pernah terduga sebelumnya. Peristiwa-peristiwa tersebut bagaikan sebuah hadiah besar yang tidak ada satu orang pun yang mengetahui isinya. Terkadang peristiwa itu membawa kebahagiaan, namun tidak jarang pula membawa kesedihan dan kesengsaraan bagi orang yang menerimanya. Menurut Kamus Besar Bahasa Indonesia (KBBI), peristiwa yang membuat individu merasa sedih dan merasa sengsara disebut sebagai sebuah tragedi atau musibah. Manusia pun tidak dapat menghindari tragedi-tragedi yang datang kepadanya,seperti bencana alam, penyakit dan bahkan kematian sekalipun.

Salah satu contoh tragedi yang terjadi pada manusia adalah terkena penyakit.Penyakit yang sering dijumpai dalam masyarakat, ada yang disebut dengan penyakit kronis. Penyakit kronis adalah penyakit yang berkepanjangan dan jarang sembuh sempurna (Herwana, 2006). Diantara penyakit kronis yang ada salah satunya adalah penyakit Diabetes Melitus.Diabetes melitus terjadi karena tingginya gula darah dalam tubuh, yaitu ketika kadar gula darah mencapai $>200$ mg/dL. Gangguan metabolisme karbohidrat pada lansia meliputi tiga hal yaitu resistensi insulin, hilangnya pelepasan insulin fase pertama sehingga lonjakan awal insuli postprandial tidak terjadi pada lansia dengan DM, peningkatan kadar glukosa postprandial dengan kadar gula glukosa puasa normal (Kurniawan, 2010).

Perkembangan Diabetes Melitus di Indonesia pun mengalami peningkatan dari tahun ke tahun. Menurut International Diabetes Federation (IDF), 371 juta orang di dunia yang berumur 20-79 tahun menderita diabetes. Tjandra Yoga Aditama sebagai Dirjen Pengendalian Penyakit dan Penyehatan Lingkungan (Dirjen P2PL) juga mengatakan bahwa Indonesia merupakan negara dengan urutan ke 7 dengan pravelensi diabetes tertinggi, dibawah Cina, India, USA, Brazil, Rusia dan Mexico (Harian Sindo, 3/9/2013). Posisi pertama adalah Cina dengan 92,3 juta penderita, India sebanyak 63 juta jiwa, Amerika Serikat 24,1 juta jiwa, Brasil 13,4 juta jiwa, Rusia 12,7 juta jiwa, Meksiko 10,6 juta jiwa, dan Indonesia dengan jumlah penderita diabetes sebanyak 7,6 juta orang (Tempo,5/9/2013).

Diabetes Melitus merupakan penyakit kronis yang tidak dapat sembuh namun masih dapat dikontrol dengan obat dan pola hidup sehat. Menurut WHO (World Health Organization) diabetes dibagi menjadi beberapa kelompok. Tipe pertama adalah Insulin Dependent Diabetes Melitus (IDDM). Diabetes Melitus tipe ini merupakan diabetes yang tergantung dengan insulin dari luar tubuh. Penyebabnya adalah alergi terhadap kelenjar 
Philanthropy Journal of Psychology

Vol 2 Nomor 2 (2018), 97-113

ISSN 2580-6076 (Print), ISSN 2580-8532 (Online)

pankreasnya sendiri (WHO,2006). Tipe kedua adalah diabetes melitus adalah Non Insulin Dependent Diabetes Melitus (NIDDM). Penyebab pasti dari tipe ini hingga sekarang tidak dapat dipastikan. Namun menurut Supartondo melalui wawancaranya dengan pasien, ternyata sebagian bessar pasien NIDDM memiliki riwayat keluarga penderita diabetes sehingga dapat disimpulkan bahwa faktor keterurunan memiliki faktor penting dalam menentukan munculnya NIDDM (WHO,2006). Selain itu, pola hidup dan pola makan juga mempengaruhi kemunculan diabetes melitus tipe dua ini. Tidak jarang pasien dengan penyakit kronis mengalami penurunan motivasi, sedih, takut, tidak dapat konsentrasi dengan baik dan tidak dapat optimal dalam bekerja (Paputungan, 2015). Hal ini terjadi karena banyak perubahan yang terjadi dalam kehidupan mereka. Perubahan yang cenderung mendadak membuat penderita Diabetes Melitus harus beradaptasi dengan keadaan tersebut.

Penderita Diabetes Melitus tipe II harus mengonsumsi obat-obat yang diberikan oleh dokter untuk mengontrol kadar gula dalam darah mereka. Penderita cenderung dituntut untuk mengubah gaya hidup mereka. Olah raga dan makanan yang teratur. Penderita tidak diperbolehkan untuk mengonsumsi makanan yang mengandung kadar gula yang tinggi secara berlebihan, seperti nasi, gula dan makanan-makanan manis lainnya. Konsumsi obat yang terus menerus, pola makan dan pola hidup yang selalu diatur membuat penderita terkadang merasa bosan dan jenuh. Mereka merasa penderitaan yang mereka rasakan tidak akan ada akhirnya. Perasaan ini muncul ketika individu merasa tidak ada harapan serta tidak berdaya. Menurut Kubler-Ross's reaksi ini merupakan waktu untuk 'perasaan duka terlebih dahulu ketika pasien melihat dirinya akan mati (Taylor, 1995).

Ketika mengalami musibah sangat lumrah jika individu yang tertimba akan merasa sengsara atau bahkan merasa paling menderita. Individu memiliki beragam respon terhadap masalah yang mereka hadapi.Tergantung dengan sudut pandang dan pengalaman yang telah mereka alami sebelumnya.Seperti sedih, marah atau bahkan frustasi.Namun ada beberapa orang yang mampu mengambil hikmah dan pelajaran dari musibah yang sedang mereka hadapi.Keadaan yang tidak menguntungkan bagi mereka, mereka mampu untuk merasa lega dan bahkan merasa bahagia dengan keadaan mereka saat ini.

Kebahagiaan (happiness) merupakan keadaan emosional yang positif, bersifat subjektif, sehingga setiap orang memiliki definisi tentang kebahagiaan yang berbeda-beda (Synder \& Lopez, 2007). Menurut Seligman (2005), kebahagiaan sebagai konsep yang mengacu pada emosi positif yang dirasakan individu serta aktivitas positif yang tidak 
Philanthropy Journal of Psychology

Vol 2 Nomor 2 (2018), 97-113

ISSN 2580-6076 (Print), ISSN 2580-8532 (Online)

memiliki komponen perasaan negatif, misalnya ketika individu terlibat dalam kegiatan yang sangat disukai. Setiap manusia menginginkan hidupnya lebih bahagia lagi dari hari kehari. Individu selalu mencari sesuatu yang membuat mereka bahagia, baik itu dengan harta, tahta maupun dengan pasangan hidup mereka.

Menurut Seligman (2005), ada beberapa faktor yang mempengaruhi kebahagiaan individu. Faktor-faktor tersebut ialah perkawinan, kehidupan sosial, emosi negatif, agama dan yang terakhir adalah kesehatan subjektif. Sm adalah seorang wanita berumur 48, terdiagnosis Diabetes Melitus sejak dua tahun terakhir. Penyakit ini diketahui oleh dokter ketika Sm mengalami nyeri yang hebat dan akhirnya sampai dirawat di rumah sakit selama tiga hari. Sm merasa selama ini dia tidak pernah merasakan gejala apapun, hanya saja ia sering buang air kecil ketika malam hari dan berat badannya susut drastis. Ketika terdiagnostik, ada rasa syok, takut dan khawatir. Sm mengaku bahwa dirinya sering mendengar cerita dari tetangga dan kerabat mengenai penyakit diabetes melitus yang ia derita. Sm mendengar banyak orang yang mengalami komplikasi penyakit dan akhirnya mati. Sm merasa sangat ketakutan. Sm takut jika umurnya tidak lama lagi padahal anakanaknya masih sangat kecil. Ia memikirkan nasib anak-anaknya jika ia meninggal.

Ketika Sm melihat anaknya membuat sedikit kesalahan, Sm langsung tersulut amarahnya. Sm marah karena dirinya sangat khawatir, takut jika ia meninggal anakanaknya tidak bisa bertanggung jawab akan dirinya sendiri. Hal ini membuat Sm dan anaknya menjadi kurang dekat. Setelah terdiagnostik, Sm pun jarang sekali berinteraksi dengan teman dan tetangga. Sm merasa bahwa mereka tidak akan mengerti dengan keadaan Sm sekarang. Hal ini membuat Sm merasa sangat tertekan dan tidak bahagia. Hal ini sesuai dengan pernyataan Taylor (2005) yang menyatakan bahwa hasil diagnosis penyakit kronis kerap kali membuat pasien mengalami shok. Emosi negatif Sm sangat mendominasi kehidupannya sejak terdiagniostik. Emosi negatif dan kehidupan sosial merupakan faktor-faktor yang mempengaruhi kebahagiaan. Seligman (2008) mengatakan bahwa seseorang yang semakin sering berinteraksi sosial dan memiliki emosi negatif yang rendah maka ia merupakan orang yang lebih berbahagia.

Penelitian mengenai kebahagiaan sudah banyak diteliti sebelumnya. Adapun pelatihan-pelatihan atau terapi yang pernah digunakan untuk meningkatkan kebahagiaan adalah pelatihan pemaafan, pelatihan kebersyukuran dan strategi aktivitas (bersyukur dan optimis). Pelatihan strategi aktivitas yang telah dilakukan oleh Arif dan Habibah (2015) bertujuan untuk mengetahui pengaruh pelatihan strategi aktifitas dalam meningkatkan kebahagiaan pada mahasiswa S1 Pendidikan Guru Sekolah Dasar (PGSD). Hasil dari penelitian ini mengatakan bahwa Pelatihan strategi aktivitas berpengaruh 
Philanthropy Journal of Psychology

Vol 2 Nomor 2 (2018), 97-113

ISSN 2580-6076 (Print), ISSN 2580-8532 (Online)

dalam meningkatkan kebahagiaan pada mahasiswa S1 PGSD. Pelatihan pemaafan dilakukan oleh Ridha (2014) untuk meningkatkan kebahagiaan pada anak yang orang tuanya bercerai. Subjek penelitian adalah remaja yang orang tuanya mengalami perceraian. Hasil penelitian ini mengatakan bahwa antara kelompok eksperimen dan kelompok kontrol tidak mengalami perbedaan dalam skala kebahagiaannya. Hal ini dapat diartikan bahwa pelatihan pemaafan kurang efektif untuk meningkatkan kebahagiaan mahasiswa yang orangtuanya bercerai. Hal ini disebabkan oleh kemampuan seseorang dalam memaafkan diri dan situasinya berbeda-beda satu sama lain. Ada beberapa subjek yang belum bisa memaafkan orang tua dan dirinya sehingga skor pre tes mereka cenderung sama dengan hasil skor pasca tes. Penelitian lain yang memberi intervensi untuk meningkatkan kebahagiaan adalah penelitian yang dilakukan oleh Anggarani,

Andayani dan Karyanta (2013). Penelitian ini mengangkat topik tentang pengaruh pelatihan syukur terhadap Subjective Well-Being pada penduduk miskin di Surakarta. Hasil tersebut menunjukkan bahwa pelatihan syukur berpengaruh terhadap Subjective Well-Being pada penduduk miskin di Surakarta. Penelitian yang dilakukan oleh Aesijah (2014) dengan topik "Pengaruh pelatihan Regulasi Emosi Terhadap Kebahagiaan Remaja Panti Asuhan Yatim Piatu". Subjek penelitian ini adalah remaja panti asuhan yatim piatu berusia 13-16 tahun, masih duduk di bangku SLTP baik laki-laki maupun perempuan dan jumlah subjek 19 orang. Hasil penelitian ini adalah pelatihan regulasi emosi memiliki pengaruh yang sangat signifikan terhadap kebahagiaan remaja panti asuhan yatim piatu.

Arriza, Dewi \& Kaloeti (2011) meneliti kebahagiaan yang dialami oleh penderita HIV/AIDS (ODHA) dengan mencoba memahami rekonstruksi kebahagiaan tersebut. Subjek penelitian ini terdiri dari tiga ODHA. Hasil dari penelitian ini bahwa subjek mengalami proses penyesuaian, dua subjek mengalami rekonstruksi kebahagiaan, sementara satu subjek mengalami derekonstruksi kebahagiaan. Kedua subjek tersebut melakukan perubahan afeksi untuk dapat meningkatkan kebahagiaannya, dengan mengembangkan emosi positif terhadap masa lalu (rasa syukur, rasa bangga); terhadap masa sekarang (senang ketika menolong ODHA, berafiliasi); juga terhadap masa depan (optimisme dan harapan). Penelitian mengenai hubungan antara acceptance of disability dengan kebahagiaan otentik pada penyandang disabilitas komunitas Disable Motorcycle Indonesia (DMI) (Tuzzahra \& Handadari, 2013). Hasil penelitian ini adalah adanya hubungan yang kuat antara acceptance of disability dan kebahagiaan otentik.

Mindfulness merupakan meditasi pikiran yangterkait dengan kemampuan seseorang agar mampu untuk dapat melihat hubungan antara pikiran, perasaan, dan aktivitasnya sehingga makna dan penyebab dari pengalaman dan perilaku disadari 
Philanthropy Journal of Psychology

Vol 2 Nomor 2 (2018), 97-113

ISSN 2580-6076 (Print), ISSN 2580-8532 (Online)

sepenuhnya. Pengalaman terbuka dan penerimaan memungkinkan perspektif yang lebih luas akan pikiran dan perasaannya sehingga resiko depresi dapat dikurangi bersama dengan meningkatnya kesadaran akan pikiran negatif sebagai peristiwa mental yang muncul dalam arus kesadaran (Lau \& McMain, 2005; Finucane \& Mercer, 2006).Mindfulness merupakan suatu bentuk meditasi pikiran yang melibatkan pemusatan perhatian pada setiap peristiwa dari seluruh pengalaman hidup, tanpa memperdulikan seberapa hebat pengalaman tersebut (Davis, 2007). Pandangan utama dari Mindfulness adalah "pikiran kita sendiri yang membentuk dunia" (Allen dan Knight, 2005).Sebuah studi University of California menemukan bahwa pasien yang melakukan program meditasi mindfulness dalam 8 minggu mengalami penurunan depresi dan gejala kecemasan, memiliki kontrol diri lebih baik dan kesejahteraan yang lebih tinggi(Locklear, 2011).

Mindfulness pernah diteliti oleh Hofmann (2010). Penelitian tersebut bertujuan untuk mengetahui efek mindfulness terhadap depresi dan kecemasan yang terjadi pada pasien dengan kondisi-kondisi kesehatan secara psikologis mapun secara fisik yang berbeda-beda, seperti mengalami kanker, GAD, dan depresi.Hasil dari penelitian ini mengatakan bahwa terapi mindfulness cukup efektif untuk menangani kecemasan dan gejala mood pada setiap individu yang mengikuti penelitian ini.Penelitian yang dilakukan Hofmann (2010) telah mampu untuk mengungkap pengaruh mindfulness terhadap kondisi psikologis pada tiap pasien yang memiliki latar belakang yang berbeda.Hal ini membuat penelitian yang dilakukannya kurang mendetil dalam menjelaskan antar kaitanya. Penelitian yang lain, mindfulness digunakan untuk meningkatkan kesejahteraan psikologis remaja yang difabel. Penelitian ini dilakukan oleh Kinasih dan Hadjam (2011).Penelitian ini diikuti oleh empat remaja difabel.Hasil yang diperoleh menyatakan bahwa mindfulness kurang mampu untuk meningkatkan kesejahteraan psikologis subjek secara signifikan.Hal ini dikarenakan oleh beberapa faktor yang berasal dari keadaan eksternal sehingga tidak memungkinkan subjek untuk melatih mindfulness secara mandiri dan terbatasnya waktu pelatihan karena kegiatan subjek dalam asrama.Mindfulness juga pernah digunakan sebagai terapi untuk pasien gangguan somatisasi dan fungsi somatic.Penelitian yang dilakukan oleh Fjorback (2012) ini menyatakan bahwa mindfulness dapat digunakan dan terapi yang telah diterima.Mindfulness menunjukkan mampu meningkatkan kualitas hidup para peserta penelitian dan mampu menurunkan gejala-gejala somatisasi. Penelitian yang telah dilakukan oleh Khaerani (2008) yang mengangkat topik mengenai pelatihan mindfulness untuk menurunkan kecemasan pada pederita jantung. Penelitian ini mampu membuktikan bahwa pelatihan dapat menurunkan kecemasan pada penderita jantung. 
Philanthropy Journal of Psychology

Vol 2 Nomor 2 (2018), 97-113

ISSN 2580-6076 (Print), ISSN 2580-8532 (Online)

Penelitian yang dilakukan oleh Tarwanti (2012) menggunakan mindfulness sebagai intervensi untuk meningkatkan kesejahteraan subjektif pada perawat. Hasil dari penelitian ini mengatakan bahwa pelatihan mindfulness yang dilakukan terbukti berpenguh kepada kesejahteraan subjektif perawat.

Mindfulness dapat menjadi intervensi yang tepat untuk orang-orang yang merindukan kebahagiaan, resiliensi, kesejahteraan dan kedamaian pikiran, tubuh dan jiwa.Mindfulness juga berperan sebagai kerinduan itu secara afektif bertemu, dihormati, dan memobilisasai partisipan untuk bertransformasi (Kabat-Zinn, 2003).Mindfulness lebih menunjukkan pada sebuah proses mengenai karakteristik mental seseorang yang nonjudgmental, sadar akan peristiwa saat ini, termasuk di dalamnya sensasi, pikiran, keadaan tubuh, ketidaksadaran yang dimilikinya dan lingkungan dimana ia berada saat ini. Mindfulness juga memperbesar keterbukaan, rasa ingin tahu dan penerimaan (Kabat-Zinn, 2003).

Bishop. dkk (2004) menyatakan kesadaran penuh merupakan representasi dari meningkatnya atau dipertahankannya keadaan sadar terjaga dan perhatian akan peristiwa pengalaman disini-saat ini. Kesadaran penuh memiliki dua komponen.Komponen pertama, keadaan sadar terjaga dan perhatian yaitu bahwa mindfulness dimulai ketika keadaan sadar terjaga dibawa kepada pengalaman disini-saat ini, diobservasi dan diperhatikan perubahan pemikiran, perasaan, dan sensasi sehingga mindfulness merupakan pengalaman langsung peristiwa yang terjadi diantara tubuh dan pikiran. Kedua, penerimaan terjadi ketika individu hanya memperhatikan setiap pemikiran, perasaan, dan sensasi sebagai pengalaman terbuka akan realitas saat ini-disini yang muncul dalam arus kesadaran. Brown dan Ryan (2003) mempertegas bahwa mindfulness didasari oleh meningkatnya keadaan sadar terjaga (awareness) yang terus-menerus memonitor keadaan diri dan lingkungan luar; dan adanya perhatian (attention) yang memusat sehingga menghasilkan kesadaran penuh akan pengalamannya secara lebih terbuka. Keadaan sadar terjaga adalah pengalaman subjektif dari phenomena internal dan eksternal yang merupakan appersepsi dan persepsi murni dari semua realitas peristiwa yang terjadi setiap saat.Perhatian merupakan pemusatan keadaan sadar terjaga untuk memperjelas aspek tertentu dari realitas. Pelatihan Mindfulness dipilih dalam penelitian ini dikarenakan telah diteliti sebelumnya mampu menurunkan depresi, somatisasi dan kecemasan. Selain itu, Mindfulness mampu meningkat kesadaran pada diri dan memicu kebahagiaan pada diri seseorang.

Islam merupakan agama mayoritas yang dipeluk oleh penduduk Indonesia. Hampir $80 \%$ penduduk Indonesia adalah muslim. Islam pun mengajarkan berbagai cara 
Philanthropy Journal of Psychology

Vol 2 Nomor 2 (2018), 97-113

ISSN 2580-6076 (Print), ISSN 2580-8532 (Online)

untuk mendapatkan kebahagiaan yang hakiki. Kebahagiaan hakiki yang dimaksud tidak hanya kebahagiaan yang ada di dunia namun kebahagiaan di akherak kelak (kehidupan setelah kematian). Jika di dalam mindfulness melatih untuk memusatkan perhatian pada here and now, penerimaan dan kesadaran untuk mendapatkan ketenangan dalam diri maka dalam Islam juga dikenal dengan kata khusyu' untuk mendapatkan ketenangan. Khusyu' adalah melunaknya hati, ketenangan, dan rasa rendah diri. Jika hati sudah mencapai kekhusyu'an, maka seluruh anggota tubuh lainnya akan mengikutinya, karena ia mengikuti hati (Ardianingsih, 2005). Kekhusyukan yang diperoleh di dalam hati dihasilkan dari pengenalan dan ilmu (ma'rifah) mengenai Allah SWT dan keagungan Nya (Namin, 2014).

Berdasarkan dari penjelasan di atas, maka dapat disimpulkan bahwa pelatihan mindfulness dipilih untuk menjadi intervensi di dalam penelitian ini karenakesadaran akan keadaan diri sekarang dan saat ini mampu menimbulkan perasaan sejahtera dan rasa bahagia. Mindfulness dalam penelitian ini selanjutnya akan disebut sebagai pelatihan mawas diri. Hal ini dilakukan untuk menyesuaikan dengan subjek penelitian. Pelatihan mawas diri mengandung nilai-nilai keislaman terutama nilai khusyu' pada diri seseorang, sehingga pelatihan mawas diri yang diberikan dalam penelitian dapat lebih mudah dipahami oleh peserta. Beberapa penjelasan di atas memunculkan rumusan masalah dari penelitian ini yaitu bagaimana pengaruh pelatihan mindfulnessyang di dalamnya memiliki nilai khusyu' untuk meningkatkan kebahagiaan pada penderita diabetes melitus tipe II?. Penelitian ini penting dilakukan untuk membantu para pasien yang terdiagnosa diabetes melitus tipe II dapat tetap merasakan kebahagiaan ditengah penderitaan yang mereka rasakan.

\section{Metode}

Penelitian ini menggunakan metode kuasi-eksperimen. Desain eksperimen yang digunakan adalah pre-test post-test control group design dengan pemberian pre-test sebelum perlakuan dan pemberian post-test setelah perlakuan, selain itu juga adanya kelompok eksperimen dan kelompok kontrol (Latipun, 2006).Perlakuan diberikan pada kelompok eksperimen berupa pelatihan mindfulness. Kelompok kontrol tidak diberikan pelatihan mindfulness. Pre-test diberikan sebelum pelatihan berlangsung untuk mengukur variabel kebahagiaan. Post-test diberikan setelah selesai pelatihan untuk mengetahui apakah ada perubahan pada variabel tergantung, sedangkan follow-up diberikan untuk melihat sejauh mana pengaruh pelatihan dapat berpengaruh pada kehidupan sehari-hari. 
Philanthropy Journal of Psychology

Vol 2 Nomor 2 (2018), 97-113

ISSN 2580-6076 (Print), ISSN 2580-8532 (Online)

Teknik pengambilan sampel menggunakan cara Random. Random merupakan teknik pengambilan subjek secara acak tanpa memperdulikan strata yang ada dalam populasi (Sugiyono, 2009).

Skala SHI (Steen Happiness Index) digunakan untuk mengukur variabel kebahagiaan. Alat ukur ini diadaptasi oleh Tuzzahra \& Handadari (2013) dalam penelitian yang mereka lakukan. SHI disusun berdasarkan teori yang dimiliki oleh Seligman (2005).SHI memiliki reliabilitas yang cukup tinggi yaitu 0,905. Azwar (2012) menyatakan bahwa reliabilitas dinyatakan oleh koefisien reliabilitas ( $\mathrm{rxx}^{\prime}$ ) yang angkanya berada pada rentang 0 sampai 1.00, sehingga semakin mendekati 0 maka semakin rendah reliabilitas skala dan semakin mendekati angka 1.00 maka semakin tinggi reliabilitas skala tersebut.

Teknik analisis data utama yang akan digunakan dalam penelitian ini adalah pendekatan kuantitatif, selain itu peneliti juga akan menggunakan teknik analisis data kualitatif yang dilakukan terhadap hasil observasi dan wawancara. Analisis data kuantitatif menggunakan softwareStatistical Product and Service Solution (SPSS) versi 16.00. Uji hipotesis menggunakan analisis parametrik independent sample t-test.

\section{Hasil}

Hasil uji analisis Mann- Whitney untuk memperbandingkan skor SHI adalah Z= -0.959 dan $\mathrm{p}=0.337(\mathrm{p}>0.05)$ artinya tidak ada perbedaan skor SHI pada kelompok eksperimen dan kelompok kontrol sebelum diberikan intervensi (prates). Hasil uji MannWhitneyperbandingan kebahagiaan paskates antara kelompok eksperimen dan kelompok kontrol $\mathrm{Z}=-1.200$ dan $\mathrm{p}=0,230(\mathrm{p}>0,001)$, artinya ada tidak ada perbedaan antara kelompok kontrol dan kelompok eksperimen. Saat tindak lanjut, juga tidak terdapat perbedaan skor SHI antara kelompok eksperimen dan kelompok kontrol.

Tabel 1. Tabel 13. Rangkuman Hasil Uji Mann- Whitney

\begin{tabular}{cccc}
\hline & $\mathbf{Z}$ & $\mathbf{p}$ & Keterangan \\
\hline Prates & -0.959 & 0.337 & Tidak Signifikan \\
Paskates & -1.200 & 0.230 & Tidak Signifikan \\
Tindak lanjut & -0.450 & 0.786 & Tidak Signifikan \\
\hline
\end{tabular}

Berdasarkan hasil uji hipotesis, dapat disimpulkan bahwa intervensi pelatihan mindfulness tidak mempengaruhi kebahagiaan penderita diabetes melitus tipe II. 
Philanthropy Journal of Psychology

Vol 2 Nomor 2 (2018), 97-113

ISSN 2580-6076 (Print), ISSN 2580-8532 (Online)

Terdapat perubahan rerata skor SHIkelompok eksperimen, yaitu dari 63.4 pada saat prates menjadi 70.4 pada paskates.Skor rerata prates tersebut dalam skala SHI tergolong dalam kategori sedang dan skor rerata paskates tersebut termasuk dalam kategori tinggi. Perubahan rata-rata skor juga terjadi di dalam kelompok kontrol. Saat prates, rata-rata skor SHI pada kelompok kontrol 64 (kategori sedang) menjadi 65 (katerogi sedang) pada saat paskates.

Kelompok kontrol yang tidak diberikan intervensi juga mengalami peningkatan.Dua minggu dari berakhirnya intervensi pada kelompok eksperimen, kedua kelompok diberi pengukuran lanjutan untuk melihat sejauh mana subjek menerapkan materi dan keterampilan yang telah didapatkan dari pelatihan. Hasil pengukuran lanjutan pada kelompok eksperimen menunjukkan adanya peningkatan kembali skor rerata kualitas hidup, yaitu menjadi 253,6 yang termasuk dalam kategori tinggi. Hasil pengukuran tindak lanjut pada kelompok kontrol juga menunjukkan adanya peningkatan rerata skor kualitas hidup menjadi 198,6 yang termasuk dalam kategori sedang.

Berdasarkan hasil tersebut dapat disimpulkan bahwa dalam kurun waktu dua minggu efek intervensi pada kelompok eksperimen sudah tidak ada pada kelompok eksperimen. Hal ini dikarenakan beberapa faktor yang memperngaruhi kebahagiaan penderita diabetes melitus tipe II.

\section{Diskusi}

Berdasarkan data yang diperoleh, dapat diketahui bahwa terdapat perbedaan skor SHI pada kelompok ekperimen dan kelompok kontrol setelah pelatihan berlangsung (paskates). Namun saat tindak lanjut, antara kelompok eksperimen dan kelompok kontrol mengalami perubahan. Kelompok eksperimen mengalami penurunan skor SHI dan kelompok kontrol mengalami peningkatan skor SHI. Ketika dianalisis ternyata pelatihan mindfulness tidak memiliki pengaruh yang banyak untuk meningkatkan kebahagiaan pada penderita diabetes tipe II. Hal sesuai dengan penelitian Kinasih dan Hadjam (2011) yang mengatakan bahwa pelatihan mindfulness kurang berhasil meningkatkan kesejahteraan psikologis pada subjek yang ia teliti. Namun hal ini berkebalikan dengan hasil penelitian Tartwanti (2012) yang mengatakan bahwa pelatihan mindfulness berpengaruh pada kesejahteraan subjektif pada perawat.

Berdasarkan data yang diperoleh, empat subjek dari lima subjek mengalami peningkatan skor SHI saat paskates. Beberapa peserta mengaku bahwa pelatihan yang diberikan kepada mereka memberikan manfaat yang luar biasa, salah satunya adalah mengurangi emosi negatif dan meningkatnya keterlibatan dalam hidup. Emosi negatif yang berkurang antara lain sedih, kecewa, gelisah dan marah. Keterlibatan dalam 
Philanthropy Journal of Psychology

Vol 2 Nomor 2 (2018), 97-113

ISSN 2580-6076 (Print), ISSN 2580-8532 (Online)

kehidupanpun meningkat, ini dibuktikan dari beberapa subjek yang mengaku bahwa dirinya lebih mampu berkonsentrasi dan lebih menyenangi pekerjaannya mereka. Berdasarkan Seligman (2005) yang menyatakan bahwa kebahagiaan merupakan sebuah konsep yang mengacu pada emosi positif yang dirasakan individu serta aktivitas positif yang tidak memiliki komponen perasaan negatif. Seiring dengan berkurangnya emosi negatif yang dirasakan oleh subjek, maka emosi positif yang mereka rasakan semakin meningkat. Hal ini terlihat dari hasil sharing yang dilakukan oleh peserta setelah melakukan pelatihan, yaitu perasaan lega dan perasaan nyaman pada diri mereka. Perasaan nyaman ini tidak hanya dirasakan pada tubuh mereka namun juga nyaman secara psikologis. Beberapa subjek mengaku bahwa mereka lebih mudah mengontrol kemarahan dan lebih mampu untuk berpikir rasional terhadap apa yang mereka rasakan.

Berdasarkan data yang diperoleh, hampir seluruh subjek mengalami penurunan skor SHI seteleh dua minggu dilaksanakannya pelatihan. Hal ini berdasarkan beberapa faktor yang dialami oleh subjek, yaitu keluarga, ekonomi, lingkungan, dan kesehatan. Sesuai dengan Seligman (2005) yang mengatakan bahwa ada beberapa faktor yang mempengaruhi kebahagiaan, yaitu : perkawinan, hubungan sosial, emosi negatif, kesehatan dan agama.

Keluarga menjadi salah satu faktor yang mempengaruhi kebahagiaan seseorang. Keluarga merupakan lingkungan sosial yang terkecil dari individu. Dukungan keluarga memiliki dampak positif bagi anggota keluarganya.Arkoff (dalam Rahardjo, 2007) menyebutkan bahwa kebahagiaan juga bisa didapatkan dari tiga hal, yaitu keluarga, kesehatan, dan keberadaan orang-orang yang dikasihi. Seperti yang dialami oleh MJL, MJL dapat melalui masa beradaptasi dengan penyakit yang ia derita relatif cepat. Hal ini dikarenakan suami dan anak-anaknya yang selalu menghibur dan mengingatkan subjek bahwa dirinya tidak pernah sendiri. Berbeda dengan keadaan KNT. Selama dua minggu setelah dilaksanakan pelatihan mindfulness, KNT tetap harus merawat dan membiayai perawatan ayahnya yang sedang sakit. KNT yang masih merasa kecewa terhadap sosok ayah yang menelantarkan dirinya membuat KNT kurang dapat berdamai dengan dirinya sendiri. KNT masih sering menyalahkan ayahnya akan kondisi ayahnya sekarang dan masih sering berpikir bahwa seharusnya anak angkat ayahnya lah yang membiayai biaya perawatan. Maslow (1993) menyebutkan bahwa keluarga memberikan sebuah kebersamaan yang sifatnya primitif di mana cinta kasih akan memberikan lebih dari sekedar kenyamanan satu dengan yang lain, melainkan juga sebuah kebahagiaan yang dalam. Benokraitis (1996) bahkan mengatakan bahwa bukan hanya cinta yang diberikan oleh keluarga, namun juga dukungan emosional yang sangat membantu anggota keluarga 
Philanthropy Journal of Psychology

Vol 2 Nomor 2 (2018), 97-113

ISSN 2580-6076 (Print), ISSN 2580-8532 (Online)

berjuang melewati masa-masa sulit. Jika keluarga kurang memberikan dukungan atau memberikan luka psikologis maka hal ini memiliki dampak yang negatif pada anggota keluarganya.

Manusia adalah makhluk sosial. Mereka membutuhkan satu sama lain untuk bertahan hidup. Sehingga hubungan individu dan sosialnya turut mempengaruhi kebahagiaan seseorang. Seperti yang dialami oleh MJL. MJL mengatakan bahwa seminggu belakangan ini ia sedang sibuk mempersiapkan pernikahaan anak perempuannya. Tuntutan masyarakat mengenai sebuah pernikahan membuat MJL harus mempersiapkan segalanya, seperti renovasi rumah, hidangan pernikahan, dan acara pernikahan. MJL mengaku bahwa sebenarnya ia tidak memiliki cukup banyak uang untuk melaksanakan acara pernikahan. MJL akhirnya harus meminjam uang kesanak saudaranya. Sebenarnya ia tidak ingin menyusahkan saudara-saudaranya namun MJL tetap memaksakan diri demi menjaga menjaga dirinya dan keluarganya dari "omongan" tetangga. Di lingkungan MJL tinggal, pernikahan merupakan sebuah acara yang harus dirayakan dan harus meriah. Jika tidak dirayakan atau hanya ijab qibul saja maka biasanya akan diberitakan kurang enak dari tetangganya. Hal ini membuat MJL merasa dirinya harus membuat acara diluar kemampuannya. MJL merasa kesulitan dan kembali merasa murung. Acara pernikahan termasuk dalam kebudayaan dan adat istiadat. Hal ini dapat dikatakan bahwa budaya memiliki peran dalam membentuk kebahagiaan seseorang, seperti yang dikatakan oleh Triandis (dalam Carr, 2004) bahwa budaya dan sosial politik dapat mempengaruhi kebahagiaan seseorang.

Kesehatan subjek yang dirasakan seseorang mempengaruhi tingkat kebahagiaan. Orang yang merasa dirinya sakit walaupun sebenarnya secara fisik ia sehat maka akan merasakan penderitaan. Penderitaan yang dirasakan tidak hanya secara fisik maupun secara psikologis. Mereka selalu merasa gerak fisiknya terhalang dengan penyakit yang diderita. Kejadian terburuk adalah mereka benar-benar sakit pada akhirnya. Hal ini seperti yang terjadi pada RMS. Awalnya RMS selalu khawatir dengan kesehatannya. Ia sangat takut jika ia sakit dan merepotkan keluarganya. Kekhawatiran yang terus menerus membuat tubuhnya bereaksi dan akhirnya RMS benar-benar sakit dan harus diopname selama satu minggu. Kesehatan yang menurun pun tidak mendukung dirinya untuk melakukan meditasi. Sehingga skor kebahagiaannya pun menurun. Menurut Lyubomirsky (2007) mengatakan bahwa seseorang bisa saja merasakan ketidakbahagiaan dalam hidupnya walaupun hidupnya dikelilingi oleh segala kenyamanan, cinta, dan kesejahteraan. Keluarga subjek yang selalu memberikan perhatian tidak membuat subjek merasa bahagia. Hal ini dikarenakan perasaan dan pemikiran subjek yang selalu khawatir 
Philanthropy Journal of Psychology

Vol 2 Nomor 2 (2018), 97-113

ISSN 2580-6076 (Print), ISSN 2580-8532 (Online)

dan selalu takut dengan keadaan dirinya dan keadaan keluarganya. Peale (2009) mengatakan setiap individu dapat menciptakan kebahagiaannya sendiri setiap harinya.

Setiap manusia pasti memiliki emosi negatif dan emosi positif yang mereka rasakan setiap harinya. Emosi negatif yang dirasakan lebih dominan akan menghalangi kebahagiaan yang dirasakan oleh seseorang. Hal ini hampir dirasakan oleh seluruh peserta. Setelah dua minggu dilaksanakan pelatihan, MJL mengaku bahwa ia merasa masih bisa merasakan tenang walaupun sedang berada dalam kondisi yang sulit. KNT merasa lebih bersabar dengan sikap ayahnya yang terkadang membuat ia marah dan kesal. SWT merasa lebih bahagia karena ia menganggap dirinya lebih bermanfaat bagi lingkungannya dengan membagi ilmu yang ia peroleh dari pelatihan. SMR merasa dirinya lebih menikmati kegiatannya yang padat dan lebih bisa memahami suaminya yang dianggap keras kepala. Emosi negatif yang cenderung rendah membuat mereka lebih dapat merasakan kelegaan dibandingkan dengan RMS yang kurang mampu mengendalikan ketakutannya akan penyakit yang ia alami. Hal ini membuat ia mudah jatuh sakit. Kebahagiaan sendiri merupakan kondisi psikologis yang dirasakan individu secara subjektif (Snyder \& Lopez, 2007).

Agama merupakan panutan dan pegangan bagi setiap manusia. Nilai-nila yang diajarkan agama terutama agama islam untuk selalu berpasrah dengan ketentuan Allah SWT membantu beberapa subjek untuk lebih tenang menghadapi kehidupannya. Menurut Khavari (2006) agama merupakan faktor yang mempengaruhi kebahagiaan. Hal ini dikarenakan para pemeluk agama yang memiliki iman yang kuat lebih mungkin merasa bahagia karena agama mengajarkan tujuan hidup, mengajak mereka untuk menerima dan menghadapi berbagai permasalahan hidup dengan tenang, dan mengikat mereka dalam satu umat yang saling memberikan dukungan. Seperti yang dikatakan oleh SMR, ia mengatakan bahwa hidup yang ia miliki merupakan kehendak Allah sehingga ia hanya mampu untuk menikmatinya. Bagi SMR mengeluh merupakan kegiatan yang buang-buang waktu dan tidak akan mengubah keadaan dirinya. Kenikmatan tertinggi bagi SMR adalah tidur. Ia mengaku bahwa setelah mengikuti pelatihan mindfulness, ia lebih mudah tidur saat ia lelah. Sebelum mengikuti pelatihan ia sering mengalami kesulitan tidur.

Berdasarkan wawancara yang telah dilakukan saat tindak lanjut diketahui bahwa peserta memiliki keragaman waktu dan frenkuensi dalam memperaktekkan meditasi di rumah. Ada yang selalu memperaktekannya ada pula yang tidak pernah mempraktekkan. Peserta yang rajin memperaktekkan meditasi di rumah cenderung memiliki skor SHI dengan kategori tinggi. Berbeda dengan peserta yang jarang atau bahkan tidak pernah memperaktekkan, mereka cenderung kembali ke skor baseline. Menurunnya skor pada 
Philanthropy Journal of Psychology

Vol 2 Nomor 2 (2018), 97-113

ISSN 2580-6076 (Print), ISSN 2580-8532 (Online)

peserta tidak hanya karena tidak melakukan meditasi tapi karena bebera hal yang terkait dengan kehidupan mereka, seperti sedang menghadapi persiapan pernikahan, sakit, dan merawat orang tua yang tengah sakit. Beban-beban psikologis seperti tertekan karena kebencian pada ayah dan tuntutan masyarakat terhadap pernikahan anak seperti yang dialami oleh MJL.

Temuan yang menarik dari kelompok kontrol yang tidak diberi perlakuan. Dua peserta dari kelompok kontrol mengalami kenai skor SHI dari prates hingga tindak lanjut. Subjek pertama adalah STP, berdasarkan wawancara yang dilakukan kepadanya diketahui bahwa saat prates, subjek mengalami kecelakan dan tidak dapat bekerja seperti biasanya. STP adalah seorang laki-laki umur 42 tahun. Kesehariannya STP memiliki kegiatan rutin yang padat, yaitu: loper koran, cleaning service di salah satu universitas negeri di Yogyakarta dan disore harinya ia membantu istrinya mempersiapkan dagangan untuk dijual dipasar keesokkan harinya. Ketika subjek mengalami kecelakaan, subjek mengalami patah bagian leher sehingga ia tidak bisa melakukan pekerjaannya seperti biasa. Saat prates, subjek mengaku bahwa dirinya bosan karena tidak memiliki aktifitas dan ia merasa kasihan dengan istrinya yang harus bekerja sendiri. subjek juga merasa bahwa ia sangat bertanggung jawab dengan keadaan keluarganya sehingga ketika ia tidak bekerja ia seperti mengabaikan tanggung jawab tersebut. Saat paskates, kesehatan subjek memulih, walaupun belum diperbolehkan kerja seperti sediakala namun ia sudah diperbolehkan untuk pekerjaan ringan seperti berbelanja. Hal ini diakui subjek membuat dirinya gembira. Ia merasa sedikit berguna bagi keluarganya. Sesuai dengan skor SHI subjek yang meningkat disaat paskates. Dua minggu kemudian, subjek datang ke rumah subjek untuk melakukan tindak lanjut. Skor SHI subjek meningkat dibandingkan dengan skor SHI saat prates. Hal ini dikarenakan subjek sudah mulai kembali kerutinitas semula dan subjek merasa lebih berharga, bahagia dan lebih memiliki arti. Adler (dalam Rahardjo, 2007) mengatakan bahwa seseorang akan merasakan kebahagiaan saat dirinya telah memiliki segala hal yang baik seperti kesehatan, kemakmuran, persahabatan, pengetahuan, dan kebajikan. Namun hal ini hanya dapat diperoleh ketika seseorang melakukan aktifitas sehari-hari serta membuat banyak pilihan untuk setiap kegiatannya, bukan hanya bersikap pasif.

Subjek kedua adalah YL. YL adalah wanita berumur 53 tahun. Subjek bekerja sebagai simpan pinjam di pasar. Selain itu, subjek juga aktif berkegiatan dimasyarakat. Subjek merupakan kader puskesmas, dan ketua BKKBN. Saat prates dilakukan kepada subjek, subjek mengaku tengah mengalami kecemasan karena sebentar lagi akan ada perlombaan BKKBN di desanya. Subjek terpilih menjadi ketua dan harus 
Philanthropy Journal of Psychology

Vol 2 Nomor 2 (2018), 97-113

ISSN 2580-6076 (Print), ISSN 2580-8532 (Online)

mempresentasikan data yang diperoleh di lapangan. Selama satu minggu, subjek tidak bisa tidur dan mengalami sakit kepala yang terus menerus. Subjek juga merasa bahwa dirinya tidak memiliki waktu untuk beristirahat. Saat paskates, subjek masih merasa tidak nyaman dengan kondisi ia harus mengumpulkan data dan mempresentasikan hasilnya di depan dewan juri. Subjek sedikit mengungkapkan kejengkelannya kepada anggota BKKBN yang lain, walaupun demikian subjek sudah mampu untuk mengatasi rasa jengkel, cemas, dan lelahnya. Subjek memilih untuk tidak memikirkan apa yang akan terjadi nanti dan memilih fokus terhadap pekerjaan yang sedang ia kerjakan. Ia memasrahkan segala hasil hanya kepada Allah. Hal ini membuat ia merasa lebih nyaman dan lebih santai menjalani hidupnya. Sesuai dengan skor SHI yang diperoleh oleh subjek saat paskates. Skor SHI subjek meningkat dibandingkan sebelumnya. Saat tindak lanjut, subjek bercerita bahwa dirinya menjadi juara dua di perlombaan. Subjek merasa lega dan mengungkapkan rasa senang dan bahagia.

Berdasarkan penjelasan di atas dapat disimpulkan bahwa pelatihan mindfulness tidak memiliki pengaruh terhadap meningkatnya kebahagiaan pada penderita diabetes melitus tipe II dikarenakan beberapa faktor, seperti keluarga, budaya, emosi negatif, kesehatan dan ketakutan akan merepotkan keluarganya. Pekerjaan dan rasa puas akan yang telah dilakukannya merupakan faktor lain yang dapat meningkatkan kebahagiaan pada diri seseorang. Penelitian ini menemukan bahwa frenkuensi seseorang dalam melakukan meditasi mampu meningkatkan emosi positif dalam dirinya dan dapat merasakan kenyamanan dalam tubuhnya. Selain itu, keberhasilan pelatihan mindfulness yang paling menonjol adalah perubahan emosi negatif menjadi emosi positif yang dirasakan oleh peserta. Hampir seluruh peserta merasakan efek tenang dan lebih mampu mengontrol dirinya.

\section{Simpulan}

Hasil dari penelitian ini menunjukkan bahwa tidak terdapat perbedaan antara kelompok eksperimen dan kelompok kontrol. Adapun hasil yang lain dari penelitian ini adalah ditemukannya beberapa faktor yang dapat mempengaruhi kebagiaan seseorang seperti keluarga, budaya, emosi negatif, kesehatan dan ketakutan akan merepotkan keluarganya. Pekerjaan dan rasa puas akan pekerjaannya merupakan faktor lain yang dapat meningkatkan kebahagiaan pada diri seseorang. Penelitian ini menemukan bahwa frenkuensi seseorang dalam melakukan meditasi mampu meningkatkan emosi positif dalam dirinya dan dapat merasakan kenyamanan dalam tubuhnya. 
Rendahnya pengetahuan dan kesadaran masyarakat mengenai kesehatan diri membuat banyak pasien menolak untuk diberikan penanganan, baik berupa penanganan medis maupun penanganan secara psikologis. Penelitian selanjutnya akan lebih baik jika memberikan pengetahuan dan pengertian kepada penderita penyakit diabetes melitus pada khususnya dan pada pasien penyakit kronis pada umumnya mengenai bahaya penyakit kronis bagi fisik maupun psikisnya. Penelitian selajutnya yang hendak menjadikan mindfulness sebagai intervensinya sebaiknyamenambah sesi pertemuan, sehingga hasil yang diperoleh lebih optimal.

\section{Daftar Pustaka}

Ardianingsih, J.N. (2005). Menjernihkan Batin dengan Shalat Khusyu'.Yogyakarta: Mitra Pustaka

Arif, MF., \& Habibah, N. (2015). Pengaruh Strategi Aktivitas (Bersyukur dan Optimis) terhadap Peningkatan Kebahagiaan pada Mahasiswa S1 Pendidikan Guru Sekolah Dasar. Seminar Psikologi dan Kemanusiaan.

Azwar, S. (2000). Penyusunan Skala Psikologi. Yogyakarta : Pustaka Pelajar.

Benokraitis, N.J. (1996). Marriages and families: Changes, choices and constraints (second edition). New Jersey: Prentice Hall.

Brown, K.W., \& Ryan, R.M. (2003). The Benefit of Being Present : Mindfullness and Its Role in Psychological Well-Being. Journal of Personality \& Social Psychology, Vol. 84, No. $4,822-848$

Carr, A. (2004). Positive Psychology. The Science of Happiness and Human Strengths. New York: Brunner-Routledge

Herwana, E \& Yenny.(2006). Prevalensi penyakit kronis dan kualitas hidup pada lanjut usia di Jakarta Selatan. Universa Medicina.25.4.

Kabat-Zinn, J. (2003). Mindfulness: The heart of rehabilitation. In Leskowitz, E. (Ed.), Complementary and alternative medicinein rehabilitation (pp. xi-xv). Saint Louis:Churchill Livingstone.

Kinansih, As., \& Hadjam, MNR. (2011). Pelatihan Mindfulness untuk Meningkatkan Kesejahteraan Psikologis Remaja Difabel Fisik. Jurnal Intervensi Psikologi.3.1.4975

Kurniawan, I. (2010). Diabetes Melitus Tipe 2 pada Usia Lanjut. Maj Kedokt Indon. 60, 12.

Lyubomirsky, S.( 2007). The How of Happiness. London: Sphere

Maslow, A. (1993). Motivasi dan kepribadian 2: Teori motivasi dengan pendekatan hierarki kebutuhan manusia (edisi kedua). Alih Bahasa: Nurul Imam. Jakarta: Pustaka Binaman Pressindo.

Namin, N. (2014). Panduan Pintar Shalat Khusyu Seperti Rasulullah dan Para Sahabat. Tangerang Selatan: Sealova Media

Paputungan, K. (2015). Dinamika Psikologis Pada Orang Dengan HIV Dan AIDS (Odha). Yogyakarta: Universitas Ahmad Dahlan

Rahardjo, W. (2007). Kebahagiaan Sebagai Sebuah Proses Pembelajaran. Jurnal Penelitian Psikologi. 2. 12.

Seligman. (2005) . Authentic Happiness. Bandung: Mizan Media Utama

Steen,T.A., Park,N., \& Peterson,C. (2005) . Positive Psychology Progress:Empirical Validation of Interventions. American Psychologist, Vol. 60, No. 5, 410-421 
Snyder, C.R., \& Lopez, S.J. (2002). Handbook of Psychology Positive. New York: Oxford University Press Inc

Snyder, C.R \& Lopez, S.J. (2007). Positive Psychology : The Scientific and Pratical Explorations of Human Strengths. United Kingdom : Sage Publications, Incz

Sugiono. (2009). Metode Penelitian Kuantitatif, Kualitatif dan $R \& D$. Bandung: Alfabeta

Tarwanti, S. (2012). Pengaruh Pelatihan Mindfulness Terhadap Peningkatan Kesejahteraan Subjektif Pada Perawat. Tesis. Tidak Diterbitkan

Taylor, S.E. (1995). Health Psychology. Third Edition. New York: inc. Mc. Graw Hill.

Tuzzahra, F., \& Handadari, W. (2013). Hubungan antara Acceptance of Disability dengan Kebahagiaan Otentik pada Penyandang Disabilitas Komunitas Disable Motorcycle Indonesia (DMI). Jurnal Psikologi Kepribadian dan Sosial. 02. 01

WHO. (2006). Definition and Diagnosis of Diabetes Mellitus and Intermediate Hyperglycemia. , (2011). Beyond Authentic Happiness. Bandung: Mizan Media Utama . (2000). Reliabiltas dan Validitas. Yogyakarta : Pustaka Pelajar. 